\title{
OPTIMALISASI MODEL PEMBELAJARAN BERBASIS MASALAH DENGAN BERBANTUAN LEMBAR KERJA SISWA (LKS) UNTUK MENINGKATKAN AKTIVITAS DAN HASIL BELAJAR DALAM MATA PELAJARAN MATEMATIKA
}

\author{
Ni Made Kusumawati \\ Jurusan Pendidikan Guru Sekolah Dasar, Fakultas IImu Pendidikan \\ Universitas Pendidikan Ganesha \\ Singaraja, Indonesia \\ E-mail: kusumawati_nimade@yahoo.com
}

\begin{abstract}
Abstrak
Penelitian ini dilatarbelakangi oleh adanya permasalahan yang teridentifikasi di kelas V SDN No. 2 Batuaji yaitu rendahnya aktivitas dan hasil belajar siswa dalam mata pelajaran matematika. Tujuan penelitian ini adalah untuk mengetahui peningkatkan aktivitas dan hasil belajar dalam mata pelajaran matematika dengan mengoptimalkan model pembelajaran berbasis masalah berbantuan lembar kerja siswa (LKS) pada siswa kelas V SDN No. 2 Batuaji Kecamatan Kerambitan Kabupaten Tabanan tahun pelajaran 2010/2011. Subjek penelitian ini adalah siswa kelas V SDN No. 2 Batuaji pada semester genap tahun pelajaran 2010/2011 sebanyak 19 orang. Penelitian ini dilaksanakan dalam dua siklus. Setiap siklus terdiri dari 3 kali pertemuan. Data aktivitas belajar dikumpulkan dengan lembar observasi. Data hasil belajar dikumpulkan dengan tes. Hasil analisis deskriptif menunjukkan bahwa terjadi peningkatan aktivitas belajar dari pada siklus II sebesar 5,26 dari skor rata-rata sebesar 79,08 dalam kategori cukup aktif pada siklus I menjadi 83,34 dengan kategori aktif pada siklus II, dan terjadi peningkatan hasil belajar pada siklus II sebesar 1,75 dari skor rata-rata sebesar 79,71 dengan kategori baik pada siklus I menjadi 81,46 dengan kategori baik pada siklus II. Dengan demikian, dapat disimpulkan bahwa model pembelajaran berbasis masalah dengan berbantuan lembar kerja siswa (LKS) dapat meningkatkan aktivitas dan hasil belajar siswa dalam mata pelajaran matematika di kelas V SDN No. 2 Batuaji tahun pelajaran 2010/2011.
\end{abstract}

Kata kunci: Model Pembelajaran Berbasis Masalah, Lembar Kerja Siswa (LKS), Aktivitas, Dan Hasil Belajar Matematika

\section{Pendahuluan}

Pendidikan adalah usaha sadar dan terencana untuk mewujudkan suasana belajar dan proses pembelajaran agar peserta didik secara aktif mengembangkan potensi dirinya untuk memiliki kekuatan spiritual keagamaan, pengendalian diri, kepribadian, kecerdasan, akhlak mulia, serta keterampilan yang diperlukan dirinya, masyarakat, bangsa, dan negara (UU No. 20 Tahun 2003). Menurut Wahyudin (2007:4.44) "pendidikan nasional dewasa ini terus ditata dan dikembangkan dengan memberikan prioritas pada aspek-aspek yang dipandang strategis bagi masa depan bangsa dalam rangka menciptakan sistem pendidikan nasional yang mantap, berorientasi pada pencapaian tujuan pendidikan nasional, serta mampu menjawab tantangan masa kini dan masa depan".

Pendidikan adalah usaha sadar untuk menyiapkan peserta didik melalui kegiatan pembelajaran bagi peranannya di masa mendatang. "Pembelajaran berdasarkan makna leksikal berarti proses, cara, perbuatan mempelajari" (Suprijono, 2009). Dalam proses pembelajaran suatu keberhasilan akan dicapai siswa bukan hanya tergantung pada proses pembelajaran, tetapi tergantung pula dari faktor siswa itu sendiri. Karena hasil yang baik itu dipengaruhi oleh pelbagai komponen, dan terutama bagaimana aktivitas belajar siswa sebagai subjek belajar. 
Dalam proses pembelajaran yang berlangsung di kelas sebaiknya sudah banyak melibatkan aktivitas siswa dalam belajar. Para siswa dituntut aktivitasnya tidak hanya untuk mendengarkan, memperhatikan dan mencerna pelajaran yang diberikan guru. Akan tetapi, juga sangat dimungkinkan para siswa aktif bertanya kepada guru pada saat guru memberikan pertanyaan, sehingga menuntut siswa untuk menjawabnya.

Matematika merupakan salah satu mata pelajaran yang menduduki peranan penting dalam pendidikan dan kehidupan masyarakat. "Matematika merupakan ilmu dasar yang sudah menjadi alat untuk mempelajari ilmu-ilmu yang lain. Oleh karena itu, penguasaan terhadap matematika mutlak diperlukan dan konsep-konsep matematika harus dipahami dengan betul dan benar sejak dini" (Prihandoko, 2006:1). Melalui observasi di SDN No. 2 Batuaji terdapat 14 orang siswa yang masih mengalami kesulitan dalam belajar matematika, sehingga hasil belajar siswa tersebut rendah. Untuk lebih jelasnya dapat dilihat pada Tabel 1.

Tabel 1.Hasil Belajar Matematika Siswa SDN No. 2 Batuaji

\begin{tabular}{cc}
\hline Nilai Siswa & Banyak Siswa \\
\hline 80 & 1 orang \\
70 & 4 orang \\
60 & 3 orang \\
50 & 5 orang \\
40 & 6 orang \\
\hline
\end{tabular}

"Matematika diajarkan pada dasarnya untuk membantu melatih pola pikir siswa agar dapat memecahkan masalah dengan kritis, logis, cermat dan tepat" (Kusumawati, 2009). Disamping itu juga agar kepribadian siswa terbentuk serta terampil menggunakan metematika dalam kehidupan sehari-hari.

Menurut (Kilpatrick, Swafford, dan Findel, 2001), disposisi matematika adalah kecenderungan (1) memandang matematika sesuatu yang dapat dipahami, (2) merasakan matematika sebagai sesuatu yang berguna dan bermanfaat, (3) meyakini usaha yang tekun dan ulet dalam mempelajari matematika akan membuahkan hasil,dan (4) melakukan perbuatan sebagai pebelajar dan pekerja matematika yang efektif. Menurut (Herman, 2006: 69) "Disposisi siswa terhadap matematika tampak pada saat mereka mengerjakan tugas yang penuh percaya diri, tanggung jawab, tekun, sabar, dan kemauan mencari alternatif lain".

Salah satu upaya peningkatan aktivitas dan hasil belajar matematika adalah penggunaan model pembelajaran yang tepat dengan materi pembelajaran yang diajarkan. Sebagai seorang guru harus dapat memilih model pembelajaran yang cocok sehingga aktivitas dan hasil belajar siswa maksimal.

Model pembelajaran berbasis masalah adalah model pembelajaran yang di dalam kegiatan pembelajaran menggunakan masalah untuk belajar. Dengan mendapatkan suatu permasalahan, siswa dapat melatih dan meningkatkan keterampilan berpikir kritis dan memecahkan masalah, serta mendapatkan pengetahuan berupa konsep-konsep penting.

Pembelajaran berbasis masalah hanya dapat terjadi jika guru dapat menciptakan lingkungan kelas yang terbuka dan membimbing pertukaran gagasan. Untuk itu perlu didukung oleh sumber belajar yang memadai bagi siswa, alat-alat menguji jawaban atas dugaan, perlengkapan kurikulum, tersedianya waktu yang cukup, serta kemampuan guru dalam mengangkat dan merumuskan masalah agar tujuan pembelajaran dapat dicapai.

Lembar Kerja Siswa (LKS) merupakan bahan pembelajaran cetak yang disusun dengan hanya menekankan pada latihan, tugas atau soal-soal untuk mendukung pembelajaran yang bermakna. Walaupun hanya menekankan 
pada hal tersebut, LKS tetap menyajikan uraian materi namun disajikan secara singkat. Dengan menggunakan LKS, siswa dapat secara luas mengembangkan diri mulai dari mengaitkan konsep-konsep yang dipelajari, melatih keterampilan memecahkan masalah, kemampuan berpikir kritis dan mengkomunikasikan ideide mereka.

Pada proses pembelajaran matematika melalui LKS diharapkan siswa benar-benar aktif dan mandiri dalam belajar, sebab dengan proses pembelajaran melalui LKS ingatan siswa mengenai apa yang dipelajarinya itu akan lebih lama dan pengetahuan lebih luas dibandingkan dengan belajar secara pasif. LKS digunakan sebagai alternatif untuk menutupi kelemahan dari pemakaian model pembelajaran yang diaplikasikan dalam pembelajaran matematika sehingga dalam penyampaian materi di depan kelas lebih efektif.

Model pembelajaran berbasis masalah mampu meningkatkan kemampuan berpikir kritis dan kreatif siswa lebih baik dibandingkan model pembelajaran langsung berdasarkan pendapat-pendapat ahli. Menurut Sanjaya (2006) bahwa strategi pembelajaran berbasis masalah dapat diartikan sebagai rangkaian aktivitas pembelajaran yang menekankan kepada proses penyelesaian masalah yang dihadapi secara ilmiah. Pada pelaksanaan model pembelajaran berbasis masalah, siswa berkelompok dan berdiskusi dalam menyelesaikan masalah yang berkaitan dengan kehidupan nyata. Sutawidjaja dan Jarnawi (2011) menyatakan "Problem solving akan banyak mencapai kesuksesan manakala problem yang disajikan dalam bahan ajar berbentuk masalah realistik dan reasonably yang kompleks." Penyelesaian masalah yang diberikan tidak tujuan akhir dari pembelajaran karena pada pembelajaran ini tidak hanya bermaksud membatu siswa menemukan penyelesaian suatu masalah, tetapi juga membantu siswa memahami fakta, konsep, keterampilan dan prinsip matematika melalui masalah (Yoni Sunaryo, 2014).

Tahapan model pembelajaran berbasis masalah menurut Arends (dalam Sutawidjaja dan Jarnawi, 2011) ada 5 fase yaitu: a. Fase orientasi siswa ke masalah b. Mengatur siswa untuk belajar c. Membantu investigasi kelompok $d$. Pengembangan dan pengadaan model atau gambar e. Menganalisis proses pemecahan masalah Menurut Suprijono (2010) bahwa pembelajaran berbasis masalah terdiri dari lima fase dan perilaku. Fase 1: memberikan orientasi tentang permasalahannya kepada siswa, fase 2: mengorganisasikan siswa untuk meneliti, fase 3: membantu investigasi mandiri dan kelompok, fase 4: mengembangkan dan mempresentasikan artefak dan exhibit dan terakhir fase 5: menganalisis dan mengevaluasi proses mengatasi masalah.

Arends (Trianto, 2009) yang menyatakan bahwa: Pembelajaran berbasis masalah (PBM) merupakan suatu model pembelajaran dimana siswa mengerjakan permasalahan yang autentik dengan maksud untuk menyusun pengetahuan mereka sendiri, mengembangkan inkuiri dan keterampilan berpikir kritis, mengembangkan kemandirian, dan percaya diriMenurut Barrow (Ismaimuza, 2010) pemberian masalah dalam PBM harus memperhatikan dan memahami jenis masalah yang diberikan. Ada dua jenis masalah secara umum yaitu masalah yang tidak terstruktur (ill'structure), kontekstual dan menarik (contextual and engaging). Menurut Slavin (Ismaimuza, 2010): Karakteristik lain dari PBM meliputi pengajuan pertanyaan terhadap masalah, fokus pada keterkaitanantar disiplin, penyelidikan authentik, kerja sama, dan menghasilkan produk atau karya yang harusdipamerkan.

Sejalan dengan pendapat yang dikemukakan oleh Slavin, menurut Pierce dan Jones (Howey et al, 2001) "Dalam pelaksanaan PBM terdapat proses yang harus dimunculkan, seperti: keterlibatan (engagement), inkuiri dan investigasi (inquiry and investigation), kinerja(performance), tanya jawab dan diskusi (debriefing)". Menurut Boud dan Felleti (1998) pembelajaran berbasis masalah adalah inovasi paling signifikan dalam pendidikan tinggi dan pendidikan untuk profesi. Lebih lanjut Boud \& Felleti (1998) menyatakan pembelajaran berdasarkan masalah (problem based 
learning) adalah suatu pendekatan untuk membelajarkan siswa dalam mengembangkan keterampilan berfikir dan keterampilan memecahkan masalah, sekaligus melatih kemandirian siswa.

Berdasarkan penelitian yang telah dilakukan oleh Ariana (2010), Sukmadewi (2010) dan Siaga (2009) menyimpulkan bahwa pembelajaran berbasis masalah dapat meningkatkan aktivitas dan hasil belajar. Sedangkan Parwata (2009) menyimpulkan bahwa pembelajaran berbasis masalah mempunyai pengaruh terhadap hasil belajar matematika siswa.

SD No. 2 Batuaji merupakan sekolah yang terletak di Desa Batuaji bagian utara Kecamatan Kerambitan Kabupaten Tabanan. SDN No. 2 Batuaji mempunyai prestasi akademik yang cukup baik. Kriteria Ketuntasan Minimal (KKM) mata pelajaran matematika di SDN No. 2 Batuaji adalah 65,00. Walaupun demikian tetap masih ada siswa yang mempunyai hasil belajar kurang. Karena rata-rata hasil belajar matematika siswa kelas $\mathrm{V}$ SDN No. 2 Batuaji pada ulangan formatif kedua di bawah KKM yaitu 54,21 maka guru perlu mengoptimalkan dan menggunakan variasi model pembelajaran yang lebih efektif untuk meningkatkan hasil belajar matematika.

Berdasarkan uraian di atas, maka penulis tertarik meneliti tentang: Optimalisasi Model Pembelajaran Berbasis Masalah dengan Berbantuan Lembar Kerja Siswa (LKS) untuk Meningkatkan Aktivitas dan Hasil Belajar dalam Mata Pelajaran Matematika di Kelas V SDN No. 2 Batuaji Kecamatan Kerambitan Kabupaten Tabanan Tahun Pelajaran 2010/2011.

\section{Metode}

Penelitian ini merupakan penelitian tindakan kelas dengan tindakan berupa penerapan model pembelajaran berbasis masalah dalam pembelajaran matematika. Penelitian ini secara umum bertujuan untuk meningkatkan aktivitas dan hasil belajar matematika di kelas $\mathrm{V}$ Sekolah Dasar Negeri No. 2 Batuaji sebagai upaya mengatasi permasalahan-permasalahan yang berhasil teridentifikasi di kelas tersebut. Selain itu, penelitian ini menuntut keterlibatan dan partisipasi kolaboratif guru matematika kelas V SDN No. 2 Batuaji.

Subyek sasaran dalam penelitian tindakan kelas ini adalah siswa kelas $\mathrm{V}$ SDN No. 2 Batuaji tahun pelajaran 2010/2011. Jumlah siswa yang menjadi subyek penelitian adalah 19 orang, dengan 9 orang siswa laki-laki dan 10 orang siswa perempuan. Subyek ini dipilih karena aktivitas belajar masih rendah dan hasil belajar matematika siswa sebagian besar masih berada di bawah KKM. Oleh karena itu, semua siswa perlu diberi tindakan untuk meningkatkan aktivitas dan hasil belajar matematikanya.

Objek penelitian tindakan kelas ini adalah aktivitas dan hasil belajar matematika siswa kelas V semester II SDN No. 2 Batuaji tahun pelajaran 2010/2011. Data yang diperlukan dalam penelitian ini meliputi data aktivitas belajar siswa dan data hasil belajar kognitif siswa. Secara rinci, metode pengumpulan data, jenis data yang akan dikumpulkan, instrumen, dan waktu pengumpulan data dalam penelitian ini disajikan dalam Tabel 2

Tabel 2 Metode Pengumpulan Data dan Instrumen

\begin{tabular}{cccc}
\hline $\begin{array}{c}\text { Metode } \\
\text { Pengumpulan Data }\end{array}$ & Jenis Data & Instrumen & Waktu \\
\hline Observasi & Aktivitas belajar & $\begin{array}{c}\text { Lembar observasi } \\
\text { LKS, formatif, dan } \\
\text { pekerjaan rumah }\end{array}$ & $\begin{array}{c}\text { Selama pertemuan } \\
\text { Selama pertemuan }\end{array}$ \\
Tes & Hasil belajar & Tes kognitif & Akhir siklus \\
\hline
\end{tabular}

Menurut Agung (2005) "metode observasi ialah suatu cara memperoleh data dengan jalan mengadakan pengamatan dan pencatatan secara sistematis tentang sesuatu objek tertentu. Observasi dilakukan jika data yang diperoleh melalui wawancara kurang merefleksikan informasi yang diinginkan" (Anggoro, 2007:5.19). 
Pendapat di atas, dapat dipertegas bahwa metode observasi pada prinsipnya merupakan suatu cara untuk memperoleh data yang lebih dominan menggunakan indera penglihatan (mata) dengan melakukan pengamatan dan pencatatan dalam proses pengukuran terhadap suatu objek atau variabel tertentu yang diselidiki dan diteliti sesuai dengan tujuan penelitian.

Metode observasi digunakan untuk mengumpulkan data aktivitas belajar siswa. Data aktivitas belajar siswa dikumpulkan menggunakan lembar observasi. Aspek aktivitas yang diukur dengan lembar observasi adalah (1) keterampilan melakukan percobaan, (2) ketepatan langkah pemecahan masalah, (3) diskusi, dan (4) menyajikan hasil kerja. Setiap aspek aktivitas diuraikan menjadi 5 indikator. Aspek pertama keterampilan melakukan percobaan terdiri dari lima indikator meliputi : kelengkapan logistik yang diperlukan, ketelitian dalam percobaan, melakukan pencatatan dalam percobaan, ketepatan melakukan percobaan, dan menata peralatan setelah percobaan. Aspek kedua ketepatan langkah pemecahan masalah terdiri dari lima indikator meliputi : memahami masalah, membuat rencana pemecahan masalah, melaksanakan rencana pemecahan masalah, mengecek kembali proses pemecahan masalah, dan menemukan berbagai alternatif pemecahan yang terbaik. Aspek ketiga diskusi terdiri dari lima indikator meliputi: keberanian mengajukan pertanyaan, keberanian menyampaikan pendapat, memberikankan tanggapan atas jawaban teman, melakukan kerjasama dalam kelompok, dan pemanfaatan lingkungan belajar. Aspek keempat menyajikan hasil kerja terdiri dari lima indikator meliputi: kerapian hasil kerja, mencatumkan rencana percobaan, menunjukan hasil percobaan, menyajikan cara pemecahan dari masalah, dan menyajikan kesimpulan. Pemberian skor pada setiap indikator adalah indikator muncul mendapat skor 1 dan indikator tidak muncul mendapat skor 0 . Skor aktivitas belajar siswa diperoleh dengan menjumlahkan skor yang diperoleh siswa untuk setiap indikator.
Metode tes dalam kaitannya dengan penelitian ialah cara memperoleh data yang berbentuk suatu tugas yang dilakukan atau dikerjakan oleh seseorang atau sekelompok orang yang dites (testee), dan dari tes tersebut dapat menghasilkan suatu data berupa skor (data interval). Nurkancana (1990:34) menyatakan, Tes adalah suatu cara mengadakan penilaian yang berbentuk suatu tugas atau serangkaian tugas yang harus dikerjakan oleh anak atau sekelompok anak sehingga menghasilkan suatu nilai tentang tingkah laku atau prestasi anak tersebut, yang dapat dibandingkan dengan nilai yang dicapai oleh anak-anak lain atau dengan nilai standar yang ditetapkan.

Pendapat di atas, masih agak mengaburkan istilah skor dan nilai. Sebenarnya skor itu bersifat kontinyu atau bersambung sedangkan nilai itu lebih bersifat diskrit atau pilah. Mengetes pada intinya sama dengan mengukur dan setiap kegiatan mengukur pada umumnya akan menghasilkan data yang bersifat skor (interval). Metode tes yang digunakan dalam penelitian ini adalah untuk memperoleh data tentang hasil belajar siswa. Data hasil belajar dikumpulkan dengan menggunakan (1) LKS, (2) formatif, (3) pekerjaan rumah dan (4) tes akhir siklus berbentuk berbentuk uraian. Butir soal diadaptasi dari soal-soal buku teks yang telah memenuhi standar isi KTSP dan dari soal buatan guru.

Setelah data dalam penelitian ini terkumpul maka selanjutnya dilakukan analisis data. Dalam menganalisis data penelitian ini dilakukan dengan menggunakan metode analisis deskriptif kuantitaif. "Metode analisis deskriptif kuantitatif adalah suatu cara pengolahan data yang dilakukan dengan jalan menyusun secara sistematis dalam bentuk angka-angka dan persentase mengenai keadaan suatu objek yang diteliti sehingga diperoleh kesimpulan umum" (Agung, 2005:60).

\section{Hasil dan Pembahasan Hasil}

Secara umum pelaksanaan penelitian tindakan di kelas sudah berjalan sesuai dengan rencana pelaksanaan 
pembelajaran yang disusun dengan mengoptimalkan model pembelajaran berbasis masalah. Hasil penelitian ini meliputi deskripsi proses pembelajaran, aktivitas belajar dan hasil belajar siswa dalam pembelajaran matematika di kelas V SDN No. 2 Batuaji.

Hasil penelitian siklus I meliputi aktivitas belajar dan hasil belajar matematika. Data aktivitas belajar diperoleh dari hasil observasi pengamat/observer berkolaborasi dengan guru matematika. Berdasarkan hasil analisis data aktivitas belajar matematika pada siklus I diperoleh skor rata-rata aktivitas belajar matematika sebesar 79,08 . Sebaran skor aktivitas belajar siswa berdasarkan kategori penggolongan data aktivitas yang telah ditetapkan seperti pada Tabel 3.

Tabel 3. Sebaran Skor Aktivitas Belajar Matematika Siswa Pada Siklus I

\begin{tabular}{lclc}
\hline No. & Tingkat Keaktifan & Kategori & Frekuensi \\
\hline 1. & $90-100$ & sangat aktif & 4 \\
2. & $80-89$ & Aktif & 5 \\
3. & $65-79$ & cukup aktif & 10 \\
4. & $55-64$ & kurang aktif & 0 \\
5. & $0-54$ & sangat kurang aktif & 0 \\
\hline
\end{tabular}

Tabel 3 menunjukkan rata-rata aktivitas belajar matematika siswa kelas $\mathrm{V}$ SDN No. 2 Batuaji berada pada kategori cukup aktif.

Sedangkan hasil analisis data menunjukkan nilai rata-rata hasil sebesar 79,71 dengan standar deviasi sebesar 7,4 dan ketuntasan belajar klasikal 94,74\%. Sebaran nilai hasil belajar siswa untuk masing-masing kategori disajikan pada Tabel 4. Selain itu, deskripsi hasil belajar matematika siswa sebelum dan setelah siklus I disajikan pada Tabel 5

Tabel 4. Sebaran Nilai Hasil Belajar Matematika Siswa Pada Siklus I

\begin{tabular}{llll}
\hline NO & Tingkat Penguasaan & Kategori & Frekuensi \\
\hline 1. & $90-100$ & sangat baik & 1 \\
2. & $80-89$ & Baik & 10 \\
3. & $65-79$ & cukup baik & 7 \\
4. & $55-64$ & kurang baik & 1 \\
5. & $0-54$ & sangat kurang baik & 0 \\
\hline
\end{tabular}

Tabel 5 Nilai Hasil Belajar Matematika Siswa Sebelum dan Setelah Siklus I

\begin{tabular}{lccc}
\hline Deskripsi & \multicolumn{3}{c}{ Hasil Belajar } \\
Rata-rata & 54,21 & 79,71 & \\
Standar Deviasi & 12,70 & 7,38 & \\
Nilai Terendah & 40,00 & 64,77 & \\
Nilai Tertinggi & 80,00 & 89,73 & \\
\hline
\end{tabular}

Berdasarkan data pada Tabel 5 dapat diketahui bahwa nilai rata-rata hasil belajar siswa pada siklus I adalah sebesar 79,71 . Sesuai dengan penetapan kategori yang ditunjukkan Tabel 3.5, nilai rata-rata hasil belajar matematika siswa klasikal berada pada kategori baik. Jika nilai ratarata ini dibandingkan dengan nilai rata-rata hasil belajar matematika siswa sebelum tindakan siklus I. Jika nilai hasil belajar setiap siswa dibandingkan dengan standar ketuntasan minimum hasil belajar matematika yang berlaku saat ini di SDN No. 2 Batuaji (yaitu sebesar 65,00), maka terdapat satu orang siswa yang dinyatakan tidak tuntas. Ini berarti ketuntasan belajar yang tercapai pada siklus I ini adalah $94,7 \%$.

Hasil penelitian siklus I menunjukkan bahwa belum semua kriteria keberhasilan penelitian ini tercapai yaitu aktivitas belajar matematika yang cukup aktif dan hasil belajar matematika yang minimal berkategori baik dengan 
ketuntasan belajar minimal sebesar $75 \%$. Dan masih terlihat adanya kekurangoptimalan model pembelajaran berbasis masalah selama siklus I dalam mengatasi permasalahan pelajaran matematika di kelas V. Hal ini terungkap dari masih adanya siswa yang belum tuntas hasil belajarnya serta pelaksanaan proses pembelajaran yang terlihat belum optimal.

Berdasarkan hasil observasi selama siklus I, telah dilaksanakan refleksi siklus I. Hasil refleksi siklus I dijadikan pijakan untuk memperbaiki tindakan pada siklus berikutnya. Berikut ini dipaparkan hasil refleksi siklus I. 1) Siwa sudah mulai aktif dalam proses pembelajaran. Hal ini dapat terlihat dari beberapa orang siswa yang mulai melakukan kegiatan bertanya dan memberikan tanggapan terhadap jawaban yang diberikan oleh temannya. 2) Hasil belajar matematika siswa sudah mengalami peningkatan dan berada pada kategori baik. Hal ini dikarenakan siswa merasa senang dalam menerima ataupun menemukan sendiri konsep dari pembelajaran yang telah berlangsung. 3) Pada

pertemuan pertama dan kedua, proses pembelajaran matematika terlihat belum optimal.

$\begin{array}{ccr}\text { Siswa } & \text { masih } & \text { melakukan } \\ \text { penyesuaian } & \text { terhadap } & \text { model }\end{array}$ pembelajaran berbasis masalah yang diterapkan. Hal ini terjadi karena siswa dihadapkan pada proses pembelajaran yang berbeda dengan proses pembelajaran matematika sebelumnya yang menggunakan model pembelajaran konvensional. 4) Siswa belum terbiasa bekerja dalam kelompok. Terlebih lagi kelompok yang heterogen berdasarkan jenis kelamin dan kemampuan akademik yang berbeda. 5) Peneliti dan guru matematika masih merasa kesulitan dalam menilai aktivitas belajar siswa. Hal ini terjadi karena banyaknya indikator aktivitas yang dinilai. 6) Selama kegiatan pembelajaran, peneliti merasakan bahwa kadar pemberian tuntunan kepada siswa masih cukup tinggi. Dengan kata lain,guru matematika dan peneliti relatif banyak memberikan tuntunan kepada siswa. Hal ini disebabkan karena keterbatasan waktu yang tersedia untuk kegiatan pembelajaran. Hal ini bisa mengakibatkan rendahnya kemandirian belajar siswa. 7) Secara umum pada siklus I, siswa belum maksimal dalam menyajikan hasil percobaannya. Mereka sering mengalami kebingungan tentang cara menyajikan hasil percobaan di depan kelas. Hal ini menyebabkan siswa belum mampu menyajikan hasil percobaan dengan baik di depan kelas. 8) Salah satu hasil refleksi yang penting dari pelaksanaan tindakan siklus I adalah mengenai pengaturan penggunaan waktu belajar. Siklus I dilaksanakan belum sesuai dengan perencanaan. Tahap percobaan dan penyusunan hasil kerja kelompok dalam pembelajaran menghabiskan banyak waktu, sehingga penyajian laporan hasil kegiatan percobaan waktunya terbatas. Ini dikarenakan ketidakdisiplinan dalam percobaan dan keterbatasan guru dalam mengelola kelas.

Berdasarkan hasil refleksi selama pelaksanaan tindakan siklus I, maka diadakan upaya untuk memperbaiki proses tindakan pada siklus II. Upaya perbaikan tersebut adalah sebagai berikut. 1) Sebagai bentuk pelayanan terhadap kebutuhan siswa dan masukan bagi penyempurnaan implementasi model pembelajaran berbasis masalah, siswa selalu diberikan kesempatan untuk mengungkapkan saran dan kesan tentang proses pembelajaran. Hal ini bertujuan agar siswa lebih nyaman dalam belajar matematika. 2) Siswa harus dibiasakan bekerja dalam kelompok. LKS dan kegiatan percobaann sebaiknya dirancang sedemikian sehingga setiap anggota kelompok saling memerlukan dan perlu bekerja sama. 3) Guru bersama peneliti perlu berkoordinasi sebelum melakukan penskoran aktivitas. Penyamaan persepsi terhadap rubrik perlu dilakukan sebelum proses observasi terkait dengan kegiatan yang akan dilakukan dalam proses pembelajaran. Selain itu perlu disiapkan guru pengganti bila guru berhalangan hadir. 4) Selama kegiatan pembelajaran, peneliti dan guru berkomitmen untuk sedikit demi sedikit mengurangi kadar pemberian tuntunan kepada siswa. Pemberian tuntunan secara lisan dapat dikurangi dengan menyusun LKS yang lebih sistematis. 5) Keterampilan 
mengkomunikasikan hasil percobaan pada siklus II harus ditingkatkan. Salah satu cara yang dapat ditempuh adalah dengan memberikan contoh atau model penyampaian hasil diskusi. Namun, yang terasa cukup penting adalah suasana belajar yang menyenangkan, bebas tekanan, dan wajar melakukan kesalahan. 6) Agar tidak mengalami masalah pengaturan penggunaan waktu belajar, maka alokasi waktu untuk setiap tahap diatur lebih proporsional mengacu pada aktivitas belajar yang dilakukan. Selain itu, kasus, permasalahan, dan fenomena yang dilibatkan dalam pembelajaran siklus II dipilih dan disesuaikan dengan alokasi waktu yang tersedia pada setiap pertemuan.

Seperti pada saat siklus I, data aktivitas belajar matematika siswa diperoleh dari hasil observasi pengamat/observer berkolaborasi dengan guru matematika. Berdasarkan hasil analisis data aktivitas belajar matematika pada siklus II diperoleh skor rata-rata aktivitas belajar matematika sebesar 84,34 . Sebaran skor aktivitas belajar siswa berdasarkan kategori penggolongan data aktivitas yang telah ditetapkan seperti pada Tabel 6

Tabel 6 Sebaran Skor Aktivitas Belajar Siswa Pada Siklus II

\begin{tabular}{llll}
\hline No & Tingkat Keaktifan & Kategori & Frekuensi \\
\hline 1. & $90-100$ & sangat aktif & 7 \\
2. & $80-89$ & aktif & 7 \\
3. & $65-79$ & cukup aktif & 5 \\
4. & $55-64$ & kurang aktif & 0 \\
5. & $0-54$ & sangat kurang aktif & 0 \\
\hline
\end{tabular}

Berdasarkan Tabel 6, rata-rata skor aktivitas belajar siswa kelas $\mathrm{V}$ SDN No. 2 Batuaji (yaitu sebesar 84,34) berada pada kategori aktif. Berdasarkan hasil penelitian terhadap aktivitas belajar matematika, dapat diketahui bahwa penelitian tindakan kelas ini telah mampu memenuhi kriteria keberhasilan dalam meningkatkan aktivitas belajar, yaitu aktivitas belajar matematika yang berada pada kategori aktif. Berdasarkan hasil analisis data, diperoleh hasil belajar matematika seperti data pada Tabel 7 .

Tabel 7 Sebaran Nilai Matematika Siswa Pada Siklus II

\begin{tabular}{lclc}
\hline No & Tingkat Keaktifan & Kategori & Frekuensi \\
\hline 1. & $90-100$ & sangat baik & 6 \\
2. & $80-89$ & baik & 5 \\
3. & $65-79$ & cukup baik & 7 \\
4. & $55-64$ & kurang baik & 1 \\
5. & $0-54$ & sangat kurang baik & 0 \\
\hline
\end{tabular}

Tabel 8 menunjukkan bahwa nilai rata-rata hasil belajar matematika siswa di siklus II adalah sebesar 81,46. Pada siklus II, satu orang siswa dinyatakan tidak tuntas karena nilainya lebih kecil daripada

syarat ketuntasan minimum yang berlaku yaitu sebesar 65,00. Ini berarti, ketuntasan belajar yang tercapai pada siklus II adalah 94,7\%. Secara lengkap, hasil belajar matematika pada saat refleksi awal, siklus I, dan siklus II disajikan pada Tabel 8.

Tabel 8 Nilai Hasil Belajar Matematika Siswa Sebelum Siklus I, Pada Siklus I, dan Siklus II

\begin{tabular}{lccc}
\hline Deskripsi & Hasil Belajar \\
& Refleksi Awal & Siklus I & Siklus II \\
\hline Rata-rata & 54,21 & 79,71 & 81,46 \\
Standar deviasi & 12,70 & 7,38 & 9,46 \\
Nilai terendah & 40,00 & 64,77 & 55,40 \\
Nilai tertinggi & 80,00 & 89,73 & 94,00 \\
Ketuntasan belajar & 26,32 & 94,74 & 94,74 \\
\hline
\end{tabular}


Jika nilai hasil belajar pada siklus II ini dibandingkan dengan nilai hasil belajar matematika siswa sebelum tindakan siklus I dan setelah siklus I, maka diketahui adanya peningkatan nilai rata-rata hasil belajar matematika siswa. Data pada Tabel 4.8 menunjukkan bahwa terjadi peningkatan nilai rata-rata sebesar 25,5 dari saat sebelum dan sesudah tindakan siklus I serta peningkatan sebesar 1,75 terjadi dari siklus I ke siklus II. Hasil penelitian siklus II menunjukan bahwa semua kriteria keberhasilan penelitian ini telah tercapai yaitu aktivitas belajar matematika yang berada pada kategori aktif dan hasil belajar matematika yang berada pada kategori baik dengan ketuntasan minimal sebesar $75 \%$.

Berdasarkan hasil observasi selama siklus II, telah dilaksanakan refleksi siklus II. Berikut dipaparkan hasil refleksi siklus II. 1) Siswa mulai aktif bertanya, memberikan tanggapan, dan berinteraksi dengan siswa lain selama proses pembelajaran setelah bekerja secara berkelompok dan mendapatkan motivasi dari guru. 2) Dalam proses pembelajaran terlihat kedisiplinan siswa meningkat setelah mendapatkan pengawasan dan bimbingan secara intensif dari guru. 3) Siswa mulai terbiasa bekerja sendiri atau bekerja secara berkelompok dengan siswa lain dikarenakan pemberian tuntunan dari guru sedikit demi sedikit di kurangi. 4) Siswa semakin aktif dan bersemangat dalam mengikuti pembelajaran dikarenakan setiap aktivitas yang dilakukan siswa mendapatkan skor. 5) Masih ada seorang siswa yang memperoleh nilai hasil belajar dibawah KKM yang telah ditetapkan. Hasil refleksi pada siklus ini digunakan sebagai rekomendasi bagi guru mata pelajaran matematika yang ingin menerapkan model pembelajaran berbasis masalah. Adapun rekomendasi yang dapat dijadikan pertimbangan adalah sebagai berikut. 1) Membiasakan siswa bekerja secara berkelompok dapat membantu siswa aktif dalam proses pembelajaran. Bekerja secara kelompok juga dapat membantu siswa untuk belajar berinteraksi dengan siswa lain yang memiliki kemampuan heterogen. Kelompok belajar yang terbentuk diupayakan dibentuk oleh guru. 2) Pemberian motivasi di awal kegiatan belajar sangat baik dilakukan dengan cara menyampaikan tujuan pembelajaran dan menggali pengetahuan awal siswa melalui pertanyaan lisan atau tertulis. Hal ini dapat meningkatkan aktivitas belajar siswa dalam berinteraksi secara aktif di dalam proses pembelajaran. 3) Melaksanakan pengawasan dan bimbingan secara intensif kepada siswa dapat meningkatkan kedisiplinan dalam melaksanakan kegiatan pembelajaran. 4) Pemberian tuntun terhadap siswa dikurangi sedikit demi sedikit agar siswa terbiasa bekerja sendiri atau bekerja secara kelompok dengan siswa lain. Hal ini dilakukan untuk memberikan kesempatan secara terbuka kepada siswa belajar berdasarkan gagasan, ide atau pemikiran yang muncul dari pengalaman yang mereka dapatkan sebagai hasil dari kegiatan pembelajarannya. 5) Pemberian skor terhadap semua aktivitas belajar siswa menyebabkan siswa semakin aktif untuk melaksanakan kegiatan pembelajaran. 6) Pemberian penghargaan atas usaha yang dilaksanakan siswa melalui pujian, menyebabkan siswa semangat untuk terus berusaha. Hal ini dapat meningkatkan kepercayaan diri siswa dan menghilangkan rasa takut untuk

berpendapat. 7) Pemberian remidial terhadap siswa yang memperoleh nilai di bawah KKM yang ditetapkan, memberikan kesempatan kepada siswa untuk memperbaiki nilai yang diperolehnya.

\section{Pembahasan}

Berdasarkan analisis terhadap proses pelaksanaan optimalisasi model pembelajaran berbasis masalah pada siklus I dan siklus II, terungkap bahwa pada siklus I kegiatan pembelajaran terlihat belum optimal. Hal ini ditunjukkan dari adanya beberapa kemampuan dan perilaku siswa yang belum sesuai dengan harapan. Misalnya, masih terdapat siswa yang tidak berani mengemukakan pendapat, bertanya, atau menanggapi jawaban teman. Hasil penelitian siklus I juga menunjukkan bahwa masih ada siswa yang tidak mampu mencapai syarat ketuntasan minimum hasil belajar. Segala 
bentuk ketidakoptimalan yang terjadi pada siklus I ini kemudian dijadikan bahan refleksi siklus I. Hasil refleksi siklus I tersebut kemudian dijadikan pijakan untuk proses pembelajaran pada siklus II.

Berdasarkan hasil penelitian pada siklus II, terungkap bahwa terjadi peningkatan aktivitas belajar siswa dari siklus I. Hasil analisis data menunjukkan bahwa skor rata-rata aktivitas belajar siswa setelah siklus I sebesar 79,08 dengan standar deviasi sebesar 8,86 dan tergolong dalam kualifikasi cukup. Sedangkan skor rata-rata aktivitas belajar siswa setelah siklus II sebesar 84,34 dengan standar deviasi sebesar 7,56 dan tergolong dalam kualifikasi aktif. Terjadi peningkatan skor rata-rata dari siklus I ke siklus II sebesar 5,26. Meningkatnya aktivitas belajar siswa pada akhir siklus II disebabkan oleh beberapa upaya-upaya penyempurnaan sebagai berikut tersebut. 1) Mengoptimalkan proses pembelajaran matematika. 2) Mengoptimalkan kerjasama tim heterogen. 3) Meningkatkan kualitas penilaian aktivitas belajar siswa.

4) Mengurangi kadar pemberian tuntunan kepada siswa. 5) Memotivasi siswa dalam menyajikan hasil percobaannya.

Jika ditinjau keadaan aktivitas belajar siswa sebelum dan setelah pelaksanaan siklus I serta siklus II, maka dapat dirasakan telah terjadi perubahan tingkat aktivitas belajar pada diri siswa.

Secara kualitatif, hal ini dapat ditunjukkan dari perilaku sebagian besar siswa yang mulai aktif dan senang dengan pelajaran matematika, padahal hasil observasi sebelum siklus I menunjukkan bahwa sebagian besar siswa tidak suka dengan pelajaran matematika.

Adanya peningkatan kemampuan aktivitas belajar siswa setelah optimalisasi model pembelajaran berbasis masalah ini sejalan dengan hasil penelitian yang dilakukan oleh Ariana (2010). Hasil penelitian Ariana (2010) menunjukkan bahwa siswa yang belajar dengan model pembelajaran berbasis masalah mengalami peningkatan kemampuan aktivitas belajarnya. Hal ini semakin memperjelas implikasi dari optimalisasi model pembelajaran berbasis masalah terhadap peningkatan aktivitas belajar siswa.
Pengoptimalan

model

pembelajaran berbasis masalah merupakan salah satu pemicu terjadinya peningkatan aktivitas belajar siswa. Pelaksanaan kegiatan pembelajaran yang mengaitkan masalah-masalah sehari-hari dengan konsep pembelajaran matematika menyadarkan siswa bahwa apa yang mereka pelajari sangat bermakna bagi kehidupannya. Hal ini, memunculkan ketertarikan dan rasa senang mempelajari pelajaran matematika. Kegiatan yang dilakukan karena adanya rasa senang melakukan kegiatan tersebut akan mengurangi rasa takut melakukan suatu perubahan dan terus berusaha memperbaiki kegiatan yang telah dilakukan sebelumnya. Aktivitas belajar akan semakin meningkat jika diimbangi dengan pemberian perhatian dan penghargaan atas kerja terbaik yang telah dilakukan oleh siswa tersebut. Maka peran guru sebagai motivator sangat menentukan peningkatan aktivitas belajar siswa.

Selain aktivitas belajar matematika yang berada pada kategori aktif, hasil penelitian tindakan kelas ini juga menunjukkan adanya peningkatan nilai rata-rata hasil belajar. Nilai rata-rata hasil belajar siswa setelah siklus I sebesar 79,71 , standar deviasi sebesar 7,38, ketuntasan klasikal sebesar 94,74\%, dan berada pada kualifikasi tuntas. Nilai ratarata hasil belajar siswa pada akhir siklus II sebesar 81,46, standar deviasi sebesar 9,46 , ketuntasan klasikal sebesar 94,74\%, dan berada pada kualifikasi tuntas. Terjadi peningkatan nilai rata-rata hasil belajar siswa dari siklus I ke siklus II sebesar 1,75 . Tuntasnya hasil belajar siswa pada akhir siklus II disebabkan oleh beberapa upaya-upaya penyempurnaan sebagai berikut. 1) Memberikan kesempatan belajar secara terbuka kepada siswa dalam memecahkan permasalahan dalam kelompok. 2) Lebih banyak memberikan motivasi kepada siswa dan mengaitkan materi dengan dunia nyata siswa. 3) Mengurangi kadar pemberian tuntunan kepada siswa. 4) Memotivasi siswa dalam menyajikan hasil percobaannya.

Mengoptimalkan pengelolaan kelas.

Peningkatan aktivitas dan hasil belajar matematika yang terjadi di kelas $\mathrm{V}$ 
SDN No. 2 Batuaji pada dasarnya merupakan efek dari pelaksanaan kegiatan pembelajaran dengan model pembelajaran berbasis masalah. Selain dari pengoptimalan model pembelajaran berbasis masalah, peningkatan aktivitas dan hasil belajar matematika siswa dikarenakan adanya media kongkret yang digunakan siswa dalam penyelidikan. Media yang digunakan sesuai dengan permasalahan yang diangkat menimbulkan rasa senang siswa dalam menyelesaikan permasalahan yang dihadapi siswa tersebut. Maka peran guru sebagai fasilitator memberikan kontribusi dalam peningkatan aktivitas dan hasil belajar matematika siswa.

Berdasarkan hasil refleksi yang dilaksanakan, keberhasilan optimalisasi model pembelajaran berbasis masalah karena model pembelajaran berbasis masalah memiliki beberapa keunggulan seperti berikut. 1) Model pembelajaran berbasis masalah mampu meningkatkan aktivitas belajar siswa. Melalui optimalisasi model pembelajaran berbasis masalah siswa merasakan terlibat penuh dalam kegiatan belajar sehingga proses belajar menyenangkan. 2) Model pembelajaran berbasis masalah dapat menempatkan peranan guru sebagai motivator, fasilitator dan mediator dalam pembelajaran di kelas secara lebih optimal. 3) Model pembelajaran berbasis masalah dapat memberikan kesempatan kepada siswa untuk mengaplikasikan pengetahuan yang telah mereka miliki dalam dunia nyata. 4) Model pembelajaran berbasis masalah memberikan peluang bagi guru untuk

melaksanakan penilaian secara objektif pada siswa melalui observasi. Melalui rubrik penilaian yang digunakan guru dapat menghindari unsur subjektivitas dalam penilaian, namun secara objektif menilai siswa. 5) Model pembelajaran berbasis masalah dapat membelajarkan siswa untuk lebih aktif dan mampu merefleksikan kegiatan belajar, sehingga pikiran siswa sepenuhnya pada proses belajar yang berlangsung. 6) Model

pembelajaran berbasis masalah memberikan kesempatan kepada siswa untuk belajar sesuai dengan apa yang dikehendaki siswa melalui penggalian pengalaman yang dimiliki oleh siswa dan memanfaatkan pengalaman tersebut sebagai informasi awal untuk melaksanakan pembelajaran lebih lanjut. 7) Model pembelajaran berbasis masalah memberikan kesempatan kepada siswa belajar sesuai dengan kemampuannya, bagaimana menggunakan sebuah proses interaktif untuk menilai apa yang mereka ketahui, mengidentifikasi apa yang mereka ingin ketahui, mengevaluasi apa yang bisa dilaksanakan oleh siswa.

Selain keberhasilan-keberhasilan yang dicapai dalam optimalisasi model pembelajaran berbasis masalah di kelas $\mathrm{V}$ SDN No. 2 Batuaji tahun pelajaran 2010/2011, perlu juga disampaikan kelemahan dan beberapa kendala yang ditemui. Kelemahan dari siklus II ini adalah masih ada seorang siswa yang bernomor induk 844 memperoleh nilai dibawah KKM. Siswa tersebut dipandang perlu diberikan remidial sehingga dapat diharapkan nilai hasil belajarnya meningkat. Dan kendala yang dihadapi dalam optimalisasi model pembelajaran berbasis masalah di kelas V SDN No. 2 Batuaji tahun pelajaran 2010/2011 meliputi: 1) beberapa siswa belum terbiasa melaksanakan percobaan, bertanya, menyampaikan pendapat, dan berdiskusi dengan teman sekelasnya, 2) memerlukan waktu yang lama dalam memecahkan masalah, dan 3) adanya gangguan dari lingkungan, gangguan luar yang sering terjadi berasal dari siswa kelas lain yang tidak belajar di kelas dan berkeliaran di sekitar kelas.

\section{Penutup}

Berdasarkan rumusan masalah dan hasil penelitian dapat diambil simpulan sebagai berikut. 1) Optimalisasi model pembelajaran berbasis masalah dalam pembelajaran matematika dapat meningkatkan aktivitas belajar siswa kelas V Sekolah Dasar Negeri No. 2 Batuaji tahun pelajaran 2010/2011. Hal ini dapat dilihat berdasarkan nilai rata-rata aktivitas belajar matematika siswa setelah tindakan siklus I sebesar 79,08 dengan kategori cukup aktif dan pada akhir siklus II sebesar 84,34 dengan kategori aktif. Terjadi peningkatan aktivitas belajar matematika sebesar 5,26 dari siklus I ke 
siklus II. 2) Optimalisasi model pembelajaran berbasis masalah dapat meningkatkan hasil belajar matematika siswa kelas V Sekolah Dasar Negeri No. 2 Batuaji tahun pelajaran 2010/2011. Hal ini dapat dilihat berdasarkan adanya peningkatan nilai rata-rata hasil belajar matematika siswa dari refleksi awal sampai siklus II, di mana terjadi peningkatan nilai rata-rata hasil belajar matematika sebesar 25,50 dari refleksi awal ke siklus I dan terjadi peningkatan sebesar 1,76 dari siklus I ke siklus II.

Berdasarkan hasil penelitian yang diperoleh dalam penelitian tindakan kelas ini, dapat diajukan beberapa saran sebagai berikut. 1) Model pembelajaran berbasis masalah dapat digunakan oleh guru matematika sebagai salah satu alternatif dalam upaya meningkatkan aktivitas belajar matematika dan meningkatkan hasil belajar matematika siswa di kelas-kelas yang memiliki masalah sama dengan yang teridentifikasi oleh peneliti di kelas $\mathrm{V}$ SDN No. 2 Batuaji tahun pelajaran 2010/2011. 2) Hasil penelitian ini dibatasi oleh subjek sasaran penelitian yaitu kelas V SDN No. 2 Batuaji tahun pelajaran 2010/2011 dan materi pembelajaran untuk pokok bahasan penjumlahan dan pengurangan serta operasi hitung campuran berbagai bentuk pecahan (pecahan biasa atau pecahan campuran). Oleh karena itu, untuk mengetahui kemungkinan hasil penelitian terkait optimalisasi model pembelajaran berbasis masalah lainnya, peneliti menyarankan pihak lain untuk melakukan penelitian yang sejenis pada subjek sasaran dan materi pembelajaran lainnya

\section{Daftar Rujukan}

Abimanyu, Soli. 2008. Bahan Ajar Cetak Strategi Pembelajaran 3 SKS. Jakarta: Departemen Pendidikan Nasional.

Agung, A.A. Gede. 2005. Metodologi Penelitian Pendidikan. Singaraja: IKIP Negeri Singaraja.

Amir, Taufiq. 2009. Inovasi Pendidikan melalui Problem Based Learning Bagaima Pendidik Memberdayakan Pembelajar di Era Pengetahuan. Jakarta: Kencana Prenada Media Group.
Anggoro, Toha, dkk. 2007. Metode Penelitian. Jakarta: Universitas Terbuka.

Ariana, I Made. 2010. Penerapan Problem based learning untuk meningkatkan aktivitas dan prestasi belajar pecahan siswa kelas IV semester II SD negeri 5 Banyuning Tahun Pelajaran 2009/2010. Skripsi (tidak diterbitkan). Singaraja. Fakultas IImu Pendidikan, Universitas Pendidikan Ganesha.

Arnyana, Ida Bagus Putu. 2007. Buku Ajar Strategi Belajar Mengajar. Singaraja: Jurusan Pendidikan Biologi, Fakultas Pendidikan MIPA, Universitas Pendidikan Ganesha.

Astuti, Sri Ayu. 2010. Penggunaan Media Permainan Ular Tangga untuk Meningkatkan Aktivitas dan Hasil Belajar Matematika pada Siswa Kelas V di SD No. 5 Sukasada Tahun Pelajaran 2009/2010. Skripsi (tidak diterbitkan). Singaraja. Universitas Pendidikan Ganesha.

Boud \& Felleti (1998). The Challenge of Problem'Based Learning.Kogan Page. Sydney, Australia.

Dimyati dan Mudjiono. 1994. Belajar dan Pembelajaran. Jakarta: Departemen Pendidikan dan Kebudayaan.

Hamalik, Oemar. 2001. Proses Belajar Mengajar. Jakarta: PT Bumi Aksara.

Herman, T. (2005). Pembelajaran Berbasis Masalah untuk Meningkatkan Kemampuan Berpikir Matematis Tingkat Tinggi Siswa Sekolah Menengah Pertama. Disertasi pada PPs UPI Bandung.

Howey, K. R., et al. (2001). Contextual Teaching and Learning Preparing Teacher to Enhance Student Succes in The Work Place and Beyond. Washington: Eric Clearinghouse on Teaching and Teacher Education.

Ismaimuza, D. (2010). Kemampuan Berpikir Kritis dan Kreatif Matematis Siswa SMP melalui Pembelajaran Berbasis Masalah 
dengan Strategi Konflik Kognitif. Disertasi pada PPs UPI. Bandung: Tidak diterbitkan

Kilpatrick, J., Swafford, J., \& Findell, B. (2001). Adding It Up: Helping Children Learn Mathematics. Washington, DC: National Academy Press.

Kusumawati, Luky. 2009. Efektivitas Pembelajaran Matematika Menggunakan Metode Diskusi Dengan Teknik LKS Pada Siswa Kelas VII SMP N 4 CEPU. Skripsi (tidak diterbitkan). Surakarta. Fakultas Keguruan dan IImu Pendidikan, Universitas Muhammadiyah Surakarta.

Nurkancana, Wayan dan Sunartana. 1990. Evaluasi Hasil Belajar. Surabaya: Usaha Nasional

Parwata, Ida Bagus Adi. 2009. Pengaruh Pembelajaran Berbasis masalah terhadap motivasi berprestasi dan hasil belajar matematika pada siswa kelas VIII SMP Negeri 1 Banjar. Tesis (tidak diterbitkan). Singaraja. Fakultas Pascasarjana, Universitas Pendidikan Ganesha.

Prihandoko, Antonius Cahya. 2006. Pemahaman dan Penyajian Konsep Matematika secara Benar dan Menarik. Jakarta: Depdiknas.

Sanjaya, W.(2007).Strategi Pembelajaran Berorientasi Standar Proses Pendidikan. Jakarta : Kencana Prenada Media Group.

Sardiman, A.M. 2003. Interaksi dan Motivasi Belajar Mengajar. Jakarta: PT RajaGrafindo Persada.

Siaga, I Nyoman. 2009. Penerapan Model Pembelajaran Berbasis Masalah untuk Meningkatkan Aktivitas dan Hasil Belajar IPA pada Siswa Kelas VIIE SMPN 2 Banjar Tahun Pelajaran 2008-2009. Tesis (tidak diterbitkan). Singaraja. Fakultas Pascasarjana, Universitas Pendidikan Ganesha.

Siddiq, Djauhar, dkk. 2008. Bahan Ajar Cetak Pengembangan Bahan Pembelajaran SD 2 SKS. Jakarta: Depdiknas.

Subarinah, Sri. 2006. Inovasi Pembelajaran Matematika Sekolah Dasar. Jakarta: Depdiknas.
Sudijono, Anas. 2005. Pengantar Statistik Pendidikan. Jakarta: PT RajaGrafindo Persada.

Sukmadewi, Made Irma. 2010. Implementasi Model Pembelajaran Berbasis Masalah untuk Meningkatkan Hasil Belajar IPA pada Siswa Kelas V Semester II SD 2 Banjar Tegal. Skripsi (tidak diterbitkan). Singaraja. Jurusan PGSD, Universitas Pendidikan Ganesha.

Suprijono, A.(2010).Cooperative Learning Teori dan Aplikasi PAIKEM. Yogyakarta : Pustaka Pelajar.

Suprijono, Agus. 2009. Cooperative Learning Teori dan Aplikasi PAIKEM. Surabaya: Pustaka Pelajar.

Sutawijaja, A dan Jarnawi A. (2011). Pembelajaran Matematika. Jakarta:Universitas Terbuka.

Trianto. (2009). Mendesain Model Pembelajaran Innovative, Progresif. Surabaya: Kencana Prenada.

Trianto. 2010. Mendesain Model PembelajaranInovatif-Progresif : Konsep, Landasan, dan Implementasinya pada Kurikulum Tingkat Satuan Pendidikan (KTSP) . Jakarta: Kencana.

Undang-Undang Republik Indonesia No. 20 Tahun 2003 tentang Sistem Pendidikan Nasional. 2003. Jakarta: Depdiknas.

Wahyudin, Dinn, dkk. 2007. Pengantar Pendidikan. Jakarta: Universitas Terbuka

Yoni Sunaryo. 2014. Model Pembelajaran Berbasis Masalah Untuk Meningkatkan Kemampuan Berpikir Kritis Dan Kreatif Matematik Siswa SMA Di Kota Tasikmalaya. Jurnal Pendidikan dan Keguruan Vol. 1 No. 2, 2014, artikel 5. 